Теоретичні та прикладні питання

\title{
Invasive plants of the Kampinos National Park outskirts - the current state and threats to the protected area
}

\author{
ANNA BOMANOWSKA \\ IZABELLA KIRPLUK \\ ANNA OTRĘBA
}

Bomanowska A., Kirpluk I., OtręBA A. (2019). Invasive plants of the Kampinos National Park outskirts - the current state and threats to the protected area. Chornomors 'k. bot. z., 15 (2): 102-112. doi: 10.32999/ksu1990-553X/2019-15-2-1

Studies aimed at the identification of the range and the ways of spread of invasive alien plants in the Kampinos National Park (KNP) outskirts were carried out between 2012 and mid 2018. Special emphasis was placed on surveying the sites of the invasive species and diagnosing potential threats posed to the natural and semi-natural vegetation of the national park by them in rural areas. A floristic survey was carried out on the majority (93 localities) of settlement areas in the vicinity of KNP, in its buffer zone, frequently near the border of the park. Thirty-nine invasive taxa were found which may potentially pose a threat to the ecosystems of KNP. The most frequently identified species included trees and shrubs: Acer negundo, Rhus typhina, Robinia pseudoacacia, Partenocissuss inserta, and herbaceous plants: Conyza canadensis, Erigeron annuus, Solidago serotinoides, S. canadensis. Species encroaching from the settlement areas to semi-natural and natural communities include Bidens frondosa, Echinocystis lobata, Impatiens glandulifera, I. parviflora, Juncus tenuis, Lupinus polyphyllus, Reynoutria japonica, R. xbohemica and Solidago serotinoides. Most of them are species from the highest (III and IV) classes of invasiveness in Poland. The close distance to the Warsaw conurbation, and the road network developed around KNP has certainly affected the number of alien species recorded in the analysed area. Urbanized lands neighbouring the Park are still probably a source from where alien plants disperse to the protected area.

Keywords: alien flora, biological invasions, invasive species, conservation, central Poland

БОМАНОВСЬКА А., КІРПЛЮК І., ОТРЕБА А. (2019). Інвазивні рослини в околицях Національного парку Кампінос - сучасний стан та загрози для територій, що охороняються. Чорноморськ. бот. ж., 15 (2): 102-112. doi: 10.32999/ksu1990553X/2019-15-2-1

Дослідження, спрямовані на виявлення ареалу і шляхів поширення інвазивних чужорідних рослин в околицях Національного парку Кампінос (НПК), проводилися в період з 2012 по середину 2018 року. Особливу увагу було приділено обстеженню місць проживання інвазивних видів і діагностування потенціалу загрози, які вони представляють для природної і напівприродної рослинності національного парку в сільській місцевості. Флористичні обстеження було проведено в 93 населених пунктах в околицях НПК, в його буферній зоні, часто поблизу кордону парку. Було виявлено тридцять дев'ять інвазивних таксонів, які потенційно можуть становити загрозу для екосистем НПК. Найбільш часто зустрічаються види дерев і чагарників: Acer negundo, Rhus typhina, Robinia pseudoacacia, Partenocissuss insertta, а також трав'янисті рослини: Conyza canadensis, Erigeron annuus, Solidago serotinoides, $S$. canadensis. До видів, що потрапляють з районів населених пунктів в напівнатуральні і природні угруповання, відносяться Bidens frondosa, Echinocystis lobata, Impatiens glandulifera, I. parviflora, Juncus tenuis, Lupinus polyphyllus, Reynoutria japonica, R. $x$ 
bohemica i Solidago serotinoides. Більшість 3 них є видами з найвищих (III і IV) класів інвазивності у Польщі. Безпосередня відстань до Варшавської агломерації і мережа доріг навколо НПК, безумовно, вплинули на кількість чужорідних видів, зареєстрованих в аналізованій зоні. Урбанізовані землі, прилеглі до парку, як і раніше, ймовірно, є джерелом поширення чужорідних рослин до територій, що охороняються.

Ключові слова: адвентивна флора, біологічні інвазї, інвазивні види, збереження, иентральна Польщуа

БОМАНОВСКА А., КИРПЛЮК И., ОТРЕБА А. (2019). Инвазивные растения на окраинах Национального парка Кампинос - современное состояние и угрозы для охраняемой территории. Черноморск. бот. ж., 15 (2): 102-112. doi: $10.32999 / \mathrm{ksu} 1990-553 \mathrm{X} / 2019-15-2-1$

Исследования, направленные на выявление ареала и путей распространения инвазивных чужеродных растений на окраинах Национального парка Кампинос (НПК), проводились в период с 2012 по середину 2018 года. Особое внимание было уделено обследованию мест обитания инвазивных видов и диагностированию потенциала угрозы, которые они представляют для естественной и полуестественной растительности национального парка в сельской местности. Флористическое обследование было проведено в 93 населенных пунктах в окрестностях НПК, в его буферной зоне, часто вблизи границы парка. Было обнаружено тридцать девять инвазивных таксонов, которые потенциально могут представлять угрозу для экосистем НПК. Наиболее часто встречающиеся виды включают деревья и кустарники: Acer negundo, Rhus typhina, Robinia pseudoacacia, Partenocissuss insertta и травянистые растения: Conyza canadensis, Erigeron annuus, Solidago serotinoides, S. canadensis. К видам, попадающим из районов населенных пунктов в полунатуральные и естественные сообщества, относятся Bidens frondosa, Echinocystis lobata, Impatiens glandulifera, I. parviflora, Juncus tenuis, Lupinus polyphyllus, Reynoutria japonica, $R$. x bohemica и Solidago serotinoides. Большинство из них являются видами из самых высоких (III и IV) классов инвазивности в Польше. Непосредственное расстояние до Варшавской агломерации и сеть дорог вокруг НПК, безусловно, повлияли на количество чужеродных видов, зарегистрированных в анализируемой зоне. Урбанизированные земли, прилегающие к парку, по-прежнему, вероятно, являются источником распространения чужеродных растений на охраняемые территории.

Ключевые слова: адвентивная флора, биологические инвазии, инвазивные виды, сохранение, иентральная Польша

Invasions of alien species are considered one of the major threats to biodiversity and ecosystem functioning [VILÀ et al., 2009; PYŠEK, RiCHARDSON, 2010; SimBERLOFF et al., 2013]. One of the taxonomic groups with the most species having a negative impact on native biota and/or causing economic losses are plants [VILÀ et al., 2009; PYŠEK et al., 2011; RUMLEROVÁ et al., 2016]. On the list of the worst alien species in Europe, one-third (48 taxa) are vascular plants [NENTWIG et al., 2018].

Threats posed by alien plants are recognised as a relevant issue in conservation biology, and extensive evidence of the negative impact of invasive aliens on native species and native ecosystems suggests that plant invasions might decrease the potential of the protected areas to conserve nature [BARBER et al., 2004; DE POORTER, 2007; RANDS et al., 2010; FOXCROFT et al., 2017]. The spread of alien plant species makes it difficult to achieve the basic objectives of protected areas, i.e. the protection of biodiversity [PYŠEK et al., 2013; BRAUN et al., 2016]. Obviously, due to their high degree of naturalness the protected areas are more resistant to invasions by alien species than anthropogenically transformed lands [BYERS, 2002; PYŠEK et al., 2003]. However, many types of human activity disturb their ecological sustainability, enabling the penetration of invasive alien species [MCKINNEY, 2002; PAUCHARD, AlABACK, 2004; PYŠEK et al., 2011; FOXCROFT et al., 2017]. This is especially 
important for Europe, where most protected areas have a long history of anthropogenic usage [PYŠEK et al., 2003, 2013; BRAUN et al., 2016; GAZDA, SZWAGRZYK, 2016]. According to Monaco and Genovesi [2014], in total 378 invasive plant species were distributed in various types of European protected areas, and Pyšek et al. [2013] stated that the share of alien plants in some of the protected areas in Europe have reached almost $40 \%$.

Recently published papers dealing with the occurrence of invasive plant species in Polish national parks [NAJBEREK, SOLARZ, 2011; BOMANOWSKA et al., 2014b; GAZDA, SZWAGRZYK, 2016] show that this phenomena occurs in all of them. The summary list of invasive plant species threatening these areas contains 67 taxa [BOMANOWSKA et al., $2014 \mathrm{~b}$ ]. The most susceptible areas to invasions were extensive lowland objects under strong anthropogenic pressure [BOMANOWSKA et al., 2014 b], such as Kampinos National Park (KNP) located on the Mazovian Lowland and one of the biggest Polish national parks [OTRĘBA, 2008]. The vulnerability of the KNP to the invasions of alien species is the result of many factors, including the location of the protected area on flat, extensive terrain with no geographical barriers, moderate climate, dense settlement and road networks developed around the park, the close distance to the Warsaw metropolis and the development of residential areas on the periphery of the national park [OTRĘBA, FERCHMIN, 2007; OTRĘBA, 2008; BOMANOWSKA et al., 2014 a; KIRPLUK, BOMANOWSKA, 2015]. The strong urbanization pressure and the above-summarized effect of the pressure of the Warsaw conurbation, as well as many other smaller towns and villages located in the immediate vicinity of the protected area especially facilitated the encroachment and spread of alien species [KIRPLUK, 2012; KIRPLUK, BOMANOWSKA, 2015].

The aim of the study was to present the floristic composition of invasive plant species occurring in the settlement areas in the Kampinos National Park outskirts, to identify their spread, and to diagnose the potential threats posed by them to the natural and semi-natural vegetation of national park.

\section{Material and methods}

A floristic survey was carried out from 2012 to mid 2018 in 93 localities (having different administrative status) of settlement areas in the buffer zone of Kampinos National Park (KNP). A site was defined as a single village where a specific species was recorded.

In the study we analysed invasive alien species according to the definitions recommended by RICHARDSON et al. [2000], and also took into account the European strategy on invasive alien plants, which understands invasive alien species (IAS) as species whose introduction and/or spread threaten biological diversity, species that lead to specific economic losses, and species harmful to human and/or animal health [GENOVESI et al., 2015].

In the list we included: (i) invasive species in Poland according to the Regulation of the Minister of the Environment of 9th September 2011 on the list of alien plant and animal species whose introduction into the environment may threaten indigenous species or natural habitats [REGULATION..., 2011]; (ii) species listed as invasive alien species in Poland [TOKARSKA-GUZIK et al., 2012], regardless of the taxon's occurrence in KNP; (iii) species listed as invasive alien species on a regional scale [TOKARSKA-GUZIK et al., 2012] if the acreage of a specific species is increasing, posing a threat to the natural environment of KNP [BOMANOWSKA et al., 2014a]. Nomenclature of plants follows MOSYAKIN, FEDORONCHUK [1999].

For each of the selected species the following information was given: i) life span, i.e. the morphological type of the plant concerned with its adaptation to ecological conditions: annual plant, biennial plant, perennial plant, shrub, tree and climber [KLOTZ et al., 2002]; ii) classes of invasiveness of species according to TOKARSKA-GUZIK et al. [2012], i.e: I - weeds, mainly in anthropogenic habitats, or potentially invasive species, having a small number of localities, II - species in which invasive properties are already detected in some regions from 
increasing area of occupancy or number of localities, or which are invasive in other countries, III - species which occur in a few localities in large numbers or are scattered over many localities, IV - the most dangerous invasive plants. The significance of the presence of these species in Poland is fundamental.

For each species the relative frequency of occurrence was calculated [FI; BROWER, ZAR, 1984] according to the formula: $\mathrm{Fi}=(\mathrm{ji} / \mathrm{k}) \times 100 \%$, where: $\mathrm{j}-$ the number of localities in which "i" species was recorded, $\mathrm{k}$ - the total number of localities.

The similarity of invasive alien flora in individual villages was determined using the Jaccard similarity coefficient with object grouping by the unweighted pair group method [VAN EMDEN, 2008]. The software package STATISTICA PL. ver. 10 was used for the abovementioned analysis [STATSOFT Inc, 2013].

\section{Results}

As a result, 39 taxa of invasive vascular plants were found in the studied settlements (Table 1). Most of them are herbaceous plants: annuals (15 species; 38.5\%) and perennials $(15 ; 38.5 \%)$. Seven $(17.9 \%)$ woody species (shrubs and trees) and two climbers (Echinocystis lobata, Parthenocissus inserta) were also found.

Risk assessment of this group of plants showed that half of them (20 species; 51.3\%) belonged to the lowest (I and II) categories of invasiveness in Poland (Table). They were mainly common synanthropic plants, e.g.: Anthoxanthum aristatum, Conyza canadensis, Echinochloa crusgalli, Erigeron annuus, Galinsoga parviflora, Xanthoxalis stricta, Setaria glauca, S. viridis. Eighteen species (46.2\%) represented the highest (III and IV) categories of invasiveness. These were both herbaceous plants, e.g. Impatiens glandulifera, I. parviflora, Solidago canadensis, S. serotinoides and woody ones, e.g. Padus serotina, Quercus rubra, Robinia pseudoacacia.

Analysis of frequency (Fi) shows that the least frequent species $(\mathrm{Fi}<10 \%)$ were ten species: Asclepias syriaca, Bidens frondosa, Epilobium ciliatum, Juncus tenuis, Lolium multiflorum, Lupinus polyphyllus, Reynoutria sachalinensis, Lycium barbarum, Veronica persica, Xanthium albinum (Table 1).The most frequently occurring plants ( $\mathrm{Fi}>80 \%)$ were four species: Acer negundo, Conyza canadensis, Rhus typhina, Solidago serotinoides.

Investigated sites differed greatly in the number of invasive plants species, and there were from 5 to 23 taxa in individual villages (Fig. 1). Cluster analysis showed a lack of similarity between the studied objects (Fig. 2). The values of the Jaccard similarity coefficient were surprisingly low (0.2-0.5), and classification did not distinguish clear groups of the examined settlements with regard to found invasive alien plants.

\section{Discussion}

The obtained results showed that the most invasive and most frequent invasive plant species in the KNP outskirts (e.g. Impatiens parviflora, Lupinus polyphyllus, Padus serotina, Quercus rubra, Reynoutria japonica, Robinia pseudoacaccia, Solidago canadensis, S. serotinoides) are the same as most invasive on the scale of the country [TOKARSKA-GUZIK et al., 2012], but also very invasive in Europe, including protected areas [MONACO, GENOVESI, 2014]. These species are troublesome from an environmental and conservation point of view, as they can compete and even exclude native species, as well as generate economic losses [RUMLEROVÁ et al., 2016; NENTWIG et al., 2018].

Urbanized areas neighbouring KNP are a source where invasive alien plants disperse to the protected area. Some of the found taxa encroached from the outskirts of settlements to semi-natural and natural ecosystems of the national park (authors' own observations). In this group are very dangerous invasive species: e.g. Bidens frondosa, Echinocystis lobata, Impatiens glandulifera, I.parviflora, Juncus tenuis, Lupinus polyphyllus, Reynoutria japonica, $R$. xbohemica and Solidago serotinoides. Almost all species (except one, J. tenuis) are very 
Bomanowska A., Kirpluk I., Otręba A.

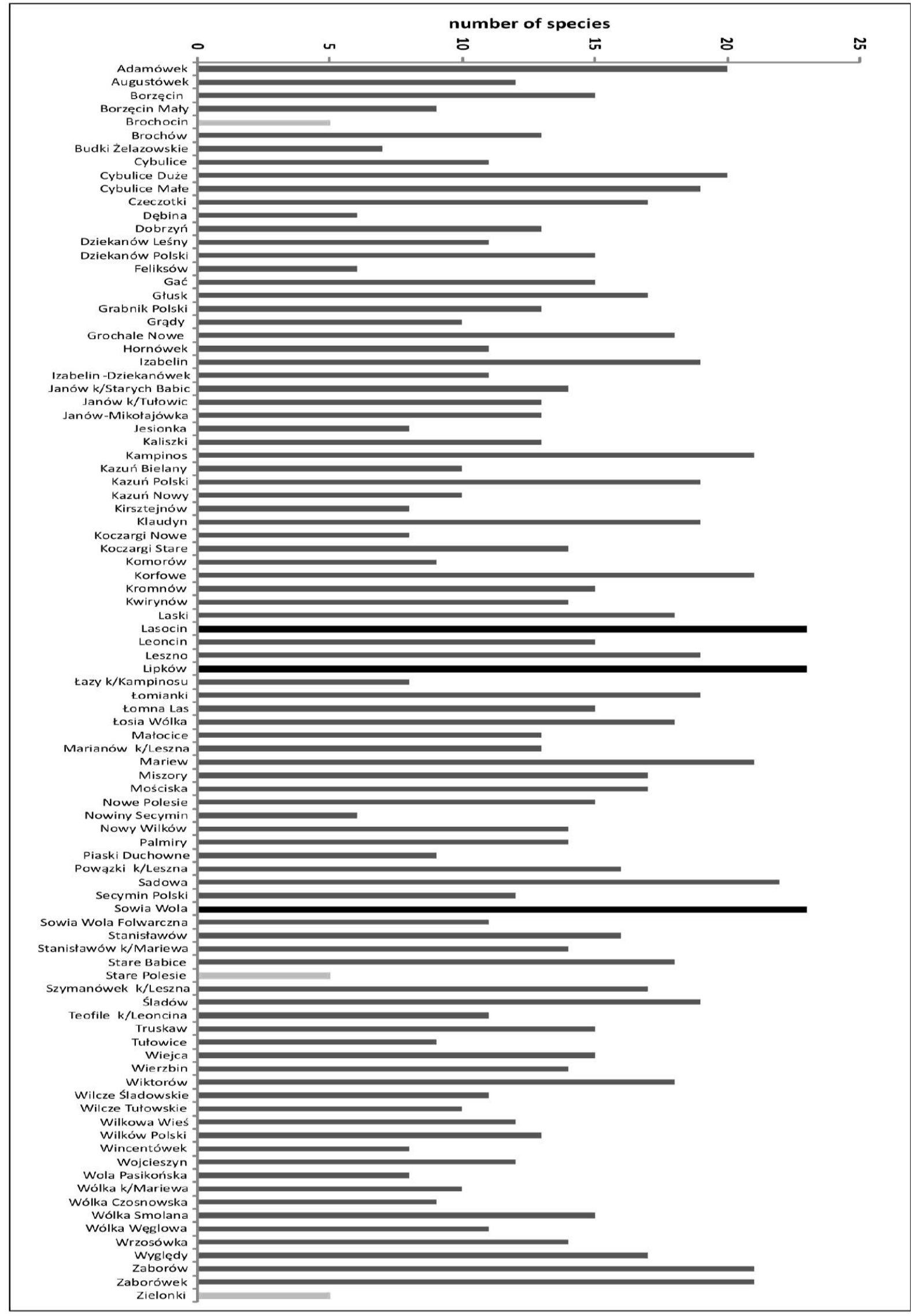

Fig. 1. The number of invasive alien species in individual sites in the vicinity of Kampinos National Park. Light gray bars - the minimum number of species, black bars - the maximum number of species. 
Invasive plants of the Kampinos National Park outskirts - the current state and threats to the protected area

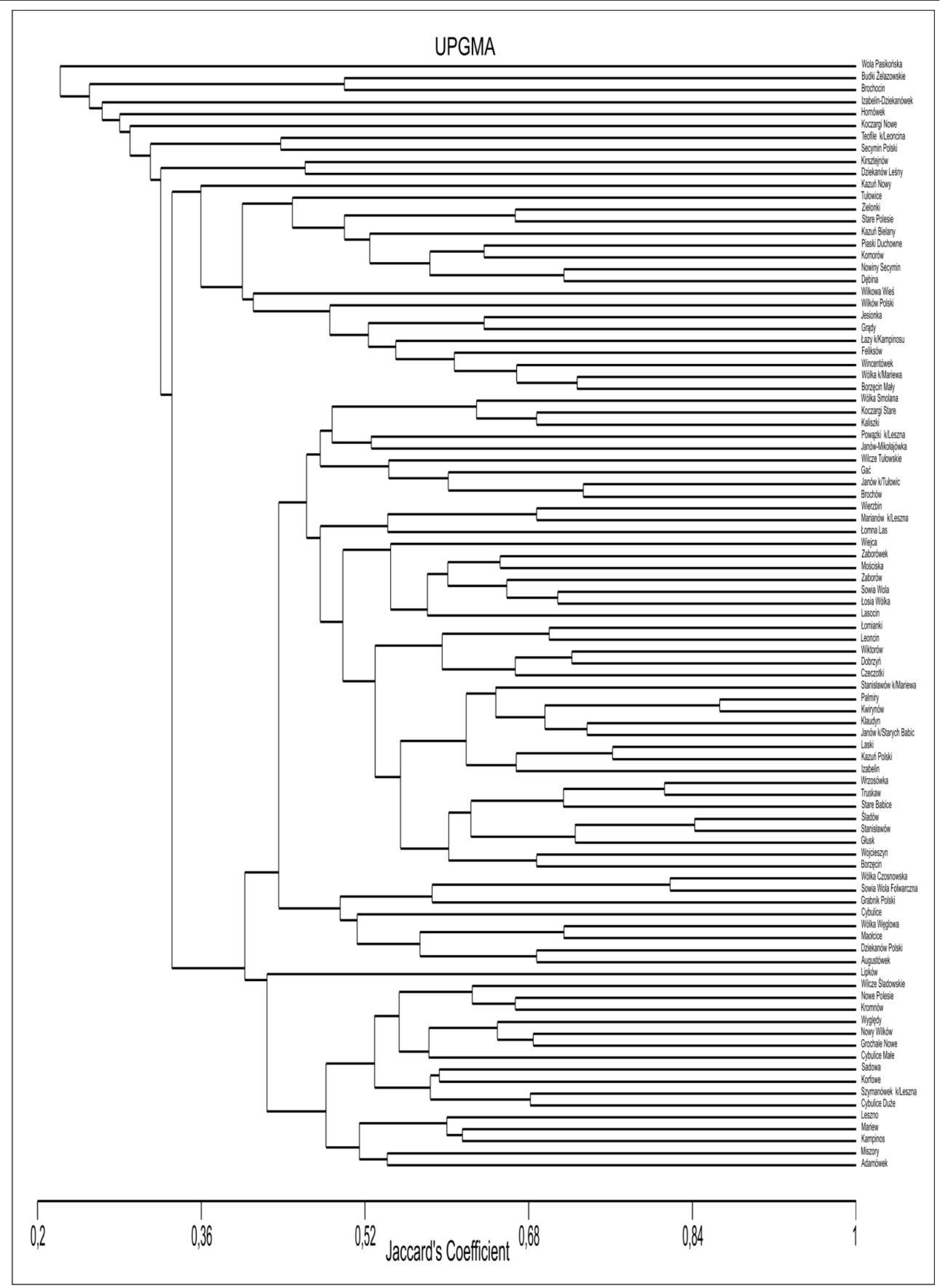

Fig. 2. Similarity of invasive alien floras of settlement areas in the vicinity of Kampinos National Park. 
Table

List of invasive vascular plant species occurring in the Kampinos National Park outskirts with their characteristics

\begin{tabular}{|c|c|c|c|c|c|c|}
\hline Species & Family & Life span & INV & $\begin{array}{l}\text { No. of } \\
\text { sites }\end{array}$ & Fi $[\%]$ & EurPAs \\
\hline Acer negundo L. & Aceraceae & tree & IV & 83 & 89.24 & + \\
\hline Amaranthus retroflexus L. & Amaranthaceae & annual & I & 39 & 41.93 & \\
\hline $\begin{array}{l}\text { Anthoxanthum aristatum } \\
\text { Boiss. }\end{array}$ & Poaceae & annual & I & 34 & 36.55 & \\
\hline Asclepias syriaca $\mathrm{L}$ & Apocynaceae & perennial & \begin{tabular}{|l|}
$\begin{array}{l}\text { potentially } \\
\text { invasive }\end{array}$ \\
\end{tabular} & 2 & 2.15 & \\
\hline Aster novi-belgii $\mathrm{L}$. & Asteraceae & perennial & IV & 22 & 23.65 & \\
\hline Avena fatua L. s.l. & Poaceae & annual & I & 10 & 10.75 & \\
\hline Bidens frondosa $\mathrm{L}$. & Asteraceae & annual & III & 7 & 7.52 & + \\
\hline $\begin{array}{|lll|}\text { Conyza } & \text { canadensis } & \text { (L.) } \\
\text { Cronq. } & & \\
\end{array}$ & Asteraceae & annual & I & 76 & 81.72 & \\
\hline $\begin{array}{l}\text { Echinochloa crusgalli (L.) } \\
\text { P.Beauv }\end{array}$ & Poaceae & annual & I & 40 & 43.01 & \\
\hline $\begin{array}{l}\text { Echinocystis lobata (Michx.) } \\
\text { Torr. \& A. Gray }\end{array}$ & Cucurbitaceae & annual/climber & IV & 46 & 49.46 & + \\
\hline Epilobium ciliatum Raf. & Onagraceae & perennial & II & 6 & 6.45 & \\
\hline Erigeron annuus (L.) Pers & Asteraceae & perennial & II & 54 & 58.06 & + \\
\hline $\begin{array}{l}\text { Galinsoga urticifolia (Kunth) } \\
\text { Benth. }\end{array}$ & Asteraceae & annual & I & 13 & 13.98 & \\
\hline Galinsoga parviflora Cav. & Asteraceae & annual & I & 42 & 45.16 & \\
\hline Helianthus tuberosus L. & Asteraceae & perennial & II & 52 & 55.91 & + \\
\hline 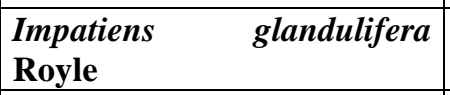 & Balsaminaceae & annual & IV & 16 & 17.2 & + \\
\hline Impatiens parviflora DC. & Balsaminaceae & annual & IV & 29 & 31.18 & + \\
\hline Juncus tenuis Willd. & Juncaceae & perennial & I & 3 & 3.22 & \\
\hline Lolium multiflorum Lam. & Poaceae & perennial & II & 5 & 5.37 & \\
\hline Lupinus polyphyllus Lindl. & Fabaceae & perennial & III & 9 & $9 ., 68$ & + \\
\hline Lycium barbarum $\mathrm{L}$. & Solanaceae & shrub & I & 7 & 7.52 & \\
\hline Xanthoxalis stricta (L.) Small & Oxalidaceae & $\begin{array}{l}\text { annual/ } \\
\text { biennial/perennial } \\
\end{array}$ & I & 16 & 17.2 & \\
\hline Padus serotina (Ehrh.) Ag. & Rosaceae & tree & IV & 17 & 18.28 & + \\
\hline \begin{tabular}{|l} 
Parthenocissus inserta (A. \\
Kerner) Fritsch
\end{tabular} & Vitaceae & shrub/climber & II & 64 & 68.82 & \\
\hline Quercus rubra L. & Fagaceae & tree & IV & 23 & 24.73 & \\
\hline $\begin{array}{l}\text { Reynoutria xbohemica } \\
\text { Chrtek \& Chrtková }\end{array}$ & Polygonaceae & perennial & IV & 30 & 32.25 & + \\
\hline Reynoutria japonica Houtt. & Polygonaceae & perennial & IV & 36 & 38.71 & + \\
\hline $\begin{array}{l}\text { Reynoutria sachalinensis (F. } \\
\text { Schmidt ex Maxim.) Nakai }\end{array}$ & Polygonaceae & perennial & IV & 3 & 3.22 & + \\
\hline
\end{tabular}


Invasive plants of the Kampinos National Park outskirts - the current state and threats to the protected area

\begin{tabular}{|c|c|c|c|c|c|c|}
\hline \multicolumn{7}{|c|}{ Table (continuation) } \\
\hline Rhus typhina $\mathrm{L}$. & Anacardiaceae & shrub/tree & II & 88 & 94.62 & \\
\hline Robinia pseudoacacia L. & Fabaceae & tree & IV & 67 & 72.04 & + \\
\hline Rosa rugosa Thunb. & Rosaceae & shrub & IV & 50 & 53.76 & \\
\hline Rudbeckia laciniata $\mathrm{L}$. & Asteraceae & perennial & IV & 40 & 43.01 & \\
\hline Rumex confertus Willd. & Polygonaceae & perennial & II & 32 & 34.41 & \\
\hline Setaria glauca (L.) P.Beauv. & Poaceae & annual & $\mathrm{I}$ & 25 & 26.88 & \\
\hline Setaria viridis (L.) P.Beauv. & Poaceae & annual & $\mathrm{I}$ & 48 & 51.61 & \\
\hline Solidago canadensis L. & Asteraceae & perennial & IV & 65 & 69.89 & + \\
\hline $\begin{array}{l}\text { Solidago serotinoides A.Löve } \\
\text { \& D.Löve }\end{array}$ & Asteraceae & perennial & IV & 84 & 90.32 & + \\
\hline Veronica persica Poir. & Scrophulariaceae & annual & I & 7 & 7.52 & \\
\hline $\begin{array}{l}\text { Xanthium albinum (Widder) } \\
\text { H. Scholz }\end{array}$ & Asteraceae & annual & IV & 1 & 1.07 & \\
\hline
\end{tabular}

Explanations: Fi - frequency; INV - category of invasiveness [according to TOKARSKA-GUZIK et al., 2012]; EurPAs - species listed as invasive in European protected areas [according to MONACO, GENOVESI, 2014]. Species listed in the Regulation of the Polish Minister of the Environment of November 11th 2011 are in bold. These species require permission and must meet certain standards for being imported, kept, cultivated/bred or traded.

dangerous invasive species from the III and IV categories of invasiveness [TOKARSKA-GUZIK et al., 2012].

According to many studies, humans and their activity are important vectors in the plant invasion process in the protected areas [e.g. ADAMOWSKI et al., 2002; MCKINNEY, 2002; PAuchard, Alaback, 2004; Allen et al., 2009; PYŠEK et al., 2011; SPEAR et al., 2013; KUDO et al., 2014]. In the case of KNP, among others, it is the intentional cultivation of ornamental plants of alien origin in cottage gardens located in settlements surrounding the national park [KIRPLUK, 2012; KIRPLUK, BOMANOWSKA, 2015]. Our results confirmed that some alien plants escaped from intentional cultivation and showed territorial expansion. Among the escapees there are highly invasive species, like Impatiens glandulifera and Reynoutria species ( $R$. japonica, $R$. xbohemica).

Despite the serious danger they pose, knotweeds are still cultivated in many gardens as ornamental plants, and are sometimes planted in the form of hedges [KIRPLUK, 2016 a]. From cultivation, knotweeds spread very easily to roadsides, dumps and other synanthropic habitats. Furthermore, the spread of Reynoutria species is enhanced through the developed network of roads, which is an important factor favouring the dispersal of invasive species by creating and maintaining roadside disturbance, and creating corridors for the transport of propagules by vehicles and road machinery [HARRISON et al,. 2002; TOKARSKA-GUZIK et al., 2012; authors' own observations]. As a result of knotweed invasion, in many places encroachment of invader into forest communities located in the vicinity of villages and roads has been observed.

Himalayan balsam, also cultivated as an ornamental plant, tends to escape from gardens the same way as knotweeds. At present, Impatiens glandulifera occurs not only in ruderal habitats, but is also found on the edges of alder and willow forests, and has invaded the banks of watercourses and reservoirs [BOMANOWSKA, ADAMOWSKI, 2016].

The negative effects of the emergence of alien species in the flora may reveal themselves after some time, and several observations suggest that some currently sparse and innocuous species could become invasive [THEOHARIDES, DUKES, 2007; BARNEY et al., 2013]. This is a serious threat to the preservation of the natural values of the protected areas [PYŠEK 
et al., 2013; BRAUN et al., 2016], which is why solutions that will enable limiting the negative impact of alien species that have already been introduced, and preventing the introduction of new species are very important [HULME et al., 2013; MONACO, GENOVESI, 2014; FOXCROFT et al., 2017]. In addition, legal regulations should prohibit the planting of foreign invasive plant species in the protection zone [KIRPLUK, 2016 b].

\section{Conclusions}

The results from our study demonstrated that urbanized lands neighbouring the Park are a source from where alien plants can disperse to the protected area. It seems that most alien species, including highly invasive taxa, escaped from intentional cultivation in cottage gardens. The close distance to the Warsaw conurbation, and the road network developed around KNP has affected the number of invasive alien species recorded in the area.

\section{Acknowledgements}

The authors are grateful to Dr. Hanna Werblan-Jakubiec, Head of the Botanic Garden, University of Warsaw, for financial support for field research and translation of the manuscript into English. We also thank $\mathrm{Mr}$ Włodzimierz Winiarski for his help in field research.

\section{References}

Adamowski W., Dvorak L., Ramanjuk I. (2002). Atlas of alien woody species of the Białowieża Primaeval Forest. Phytocoenosis 14, Supplementum Cartographiae Geobotanicae, 14: 1-303.

Allen J.A., Brown C.S., StohlgRen T.J. (2009). Non-native plant invasions of United States National Parks. Biol. Invasions, 11: 2195-2207. doi: 10.1007/s10530-008-9376-1

BARBER C.V., MiLLER K.R., BonesS M. (2004). Securing protected areas in the face of global change: issues and strategies. Gland/Cambridge: IUCN, $236 \mathrm{p}$.

BARNEY J.N., TEKIELA D.R., DOLLETE E.S.J., TOMASEK B.J. (2013). What is the "real" impact of invasive plant species? Front. Ecol. Environ., 11: 322-329. doi:10.1890/120120

BomANOWSKA A., ADAMOWSKI W. (2016). Niecierpek gruczolowaty Impatiens glandulifera Royle: 16-24. In: OBIDZIŃSKI A., KOŁACZKOwSKA E., OTRĘBA A. (eds). Metody zwalczania obcych gatunków roślin występujących na terenie Puszczy Kampinoskiej. Izabelin-Kraków: Wydawnictwo BioDar. (in Polish)

Bomanowska A., FerChmin M., KIRPLUK I., OTRĘBA A. (2014 a). Inwazyjne gatunki roślin we florze Puszczy Kampinoskiej: 25-35. In: OTR̨̨BA A., MichaLSKA-HeJduK D. (eds). Inwazyjne gatunki roślin w Kampinoskim Parku Narodowym i w jego sąsiedztwie. Izabelin: Kampinoski Park Narodowy. (in Polish)

Bomanowska A., KirPluk I., AdAmowski W., Palus J., OtręBa A. (2014 b). Problem inwazji roślin obcego pochodzenia w polskich parkach narodowych: 9-14. In: OTRĘBA A., MichALSKA-HeJdUK D. (eds). Inwazyjne gatunki roślin w Kampinoskim Parku Narodowym i w jego sąsiedztwie. Izabelin: Kampinoski Park Narodowy. (in Polish)

BRAUN M., SCHINDLER S., ESSL F. (2016). Distribution and management of invasive alien plant species in protected areas in Central Europe. J. Nat. Conserv., 33: 48-57. doi: 10.1016/j.jnc.2016.07.002

BROWER J.E., ZAR J.H. (1984). Field and laboratory methods for general ecology. Dubuque: Wm. C. Brown Company Publishers, $273 \mathrm{p}$.

BYERS J.E. (2002). Impact of non-indigenous species on natives enhanced by anthropogenic alteration of selection regimes. OIKOS, 97: 449-458. doi: 10.1034/j.1600-0706.2002.970316.x

DE POORTER M. (2007). Invasive alien species and protected areas - a scoping report. Part I. Gland/Cambridge: IUCN, $93 \mathrm{p}$.

FoXCRoft L.C., PyŠEK P., Richardson D.M., GenOvesi P., MACFAdYen S. (2017). Plant invasion science in protected areas: Progress and priorities. Biol. Invasions, 19: 1353-1378. doi: 10.1007/s10530-016$1367-\mathrm{Z}$

GaZda A., SZWAgRZYK J. (2016). Introduced species in Polish National Parks: distribution, abundance and management approaches: 168-175. In: KRUMM F., VítKOVÁ L. (eds). Introduced tree species in European forests: opportunities and challenges. Joensuu: European Forest Institute.

Genovesi P., CARboneras C., VilÀ M., Walton P. (2015). EU adopts innovative legislation on invasive species: a step towards a global response to biological invasions? Biol. Invasions, 17: 1307-1311. doi: $10.1007 / \mathrm{s} 10530-014-0817-8$

HARRISON S., HoHn C., RATAY S. (2002). Distribution of exotic plants along roads in a peninsular nature reserve. Biol. Invasions, 4: 425-430. doi: 10.1023/A:1023646016326 
Hulme P.E., PYŠEK P., Pergl J., JARošIK V., SchAFFner U., VIlÁ M. (2014). Greater Focus Needed on Alien Plant Impacts in Protected Areas. Conserv. Lett., 7: 459-466. doi: 10.1111/conl.12061

KIRPLUK I. (2012). The most recent alien species of the ruderal flora in the abandoned villages of the Kampinos National Park (Central Poland), Thaiszia - J. Bot. Kosice, 22 (2): 143-153.

KIRPLUK I. (2016 a). Gatunki z rodzaju rdestowiec Reynoutria spp.: 59-65. In: OBIDZIŃSKI A., KOŁACZKOWSKA E., OTRĘBA A. (eds). Metody zwalczania obcych gatunków roślin występujących na terenie Puszczy Kampinoskiej. Izabelin-Kraków: Wydawnictwo BioDar. (in Polish)

KIRPLUK I. (2016 b). Regulacje prawne dotyczące zwalczania obcych gatunków roślin w Polsce: 121-126. In: OBIDZIŃSKI A., KOŁACZKOWSKA E., OTRĘBA A. (eds). Metody zwalczania obcych gatunków roślin występujących na terenie Puszczy Kampinoskiej. Izabelin-Kraków: Wydawnictwo BioDar. (in Polish)

KIRPLUK I., BOMANOWSKA A. (2015). The occurrence of alien species in the settlement areas of the Kampinos National Park and its vicinity (Central Poland). Biodiv. Res. Conserv., 39: 79-90. doi 10.1515/biorc2015-0019

KLOTZ S., KÜHN I., DURKA W. (2002). BIOLFLOR - Eine Datenbank mit biologisch-ökologischen Merkmalen zur Flora von Deutschland. Schr.reihe Veg.kd., 38: 1- 334. (in German)

Kudo Y., Mutaqien Z., Simbolon H., SuZuki E. (2014). Spread of invasive plants along trails in two national parks in West Java, Indonesia. TROPICS, 23: 99-110. doi: 10.3759/tropics.23.99

MCKINNEY M.L. (2002). Influence of settlement time, human population, park shape and age, visitation and roads on the number of alien plant species in protected areas in the USA. Divers. Distrib., 8: 311 318. doi: 10.1046/j.1472-4642.2002.00153.x

Monaco A., Genovesi P. (2014). European Guidelines on Protected Areas and Invasive Alien Species. Strasbourg: Council of Europe, Lazio Region, Rome: Regional Parks Agency, 58 p.

MosyaKin S.L., FedORONCHUK M.M. (1999). Vascular plants of Ukraine: A nomenclatural checklist. Kiev: M.G. Kholodny Institute of Botany.

NAJBEREK K., SOLARZ W. (2011). Inwazje biologiczne w polskich parkach narodowych i krajobrazowych: 624639. In: GŁowACIŃSKi Z., OKARMA H., PAWŁowSKi J., SOlARZ W. (eds). Księga gatunków obcych inwazyjnych w faunie Polski. Kraków: Instytut Ochrony Przyrody. (in Polish)

Nentwig W., BACHeR S., Kumschick S., PYŠEK P., VILÀ M. (2018). More than " 100 worst” alien species in Europe. Biol. Invasions, 20: 1611-1621. doi: 10.1007/s10530-017-1651-6

OTRĘBA A. (2008). Rozprzestrzenianie się obcych inwazyjnych gatunków roślin jako zagrożenie przyrody Kampinoskiego Parku Narodowego. Dok. Geograficzna, 37: 194-204. (in Polish)

OTRĘBA A., FERCHMIN M. (2007). Obce gatunki drzew miarą przekształcenia przyrody Kampinoskiego Parku Narodowego. Studia i Materiaty CEPL w Rogowie, 16: 234-244. (in Polish)

PAUCHARD A., AlABACK P.B. (2004). Influence of elevation, land use, and landscape context on patterns of alien plant invasions along roadsides in protected areas of South-Central Chile. Conserv. Biol., 18: 238248. doi: $10.1890 / 080072$

PYŠEK P., Genovesi P., Pergl J., MonaCo A., Wild J. (2013). Plant Invasions of Protected Areas in Europe: An Old Continent Facing New Problems: 209-240. In: FOXCROFT L.C., PYŠEK P., Richardson D.M., GENOVESI P. (eds). Plant Invasions in Protected Areas Patterns, Problems and Challenges. New York: Springer. doi: 10.1007/978-94-007-7750-7

PYŠEK P., JAROŠIK V., KUCERA T. (2003). Inclusion of native and alien species in temperate nature reserves: an historical study from Central Europe. Conserv. Biol., 17: 1414-1424. doi: 10.1046/j.15231739.2003.02248.x

PYŠEK P., JAROŠIK V., PERGL J. (2011). Alien Plants Introduced by Different Pathways Differ in Invasion Success: Unintentional Introductions as a Threat to Natural Areas. PLoS ONE, 6: e24890. doi:10.1371/journal.pone.0024890

PYŠEK P., RICHARDSON D.M. (2010). Invasive Species, Environmental Change and Management, and Health. Annu. Rev. Environ. Resour., 35: 25-55. doi: 10.1146/annurev-environ-033009-095548

Rands M.R.W., Adams W.M., Bennun L., Butchart S.H.M., Clements A., CoOmes D., Entwistle A., Hodge I., Kapos V., Scharlemann J.P.W., Sutherland W.J., VIRA B. (2010). Biodiversity Conservation: Challenges Beyond 2010. Science, 329: 1298-1303. doi: 10.1126/science.1189138

REgulation 2011. The Regulation of the Minister of the Environment dated 9 September 2011 on alien plant and animal species whose introduction into the environment may threaten indigenous species or natural habitats. Journal of Laws of 2011, No. 210, item 1260.

Richardson D.M., PYŠEK P., REJMÁNEK M., BARbour M.G., PANETTA F.D., WeST C.J. (2000). Naturalization and invasion of alien plants: concepts and definitions. Divers. Distrib., 6: 93-107. doi: 10.1046/j.1472-4642.2000.00083.x

Rumlerová Z., VilÀ M., Pergl J., NenTwig W., PyŠEK P. (2016). Scoring environmental and socioeconomic impacts of alie plants invasive in Europe. Biol. Invasions, 18: 3697-3711. doi: 10.1007/s10530 016-1259-2 
Simberloff D., Martin J.-L., Genovesi P., Maris V., Wardle D.A., Aronson J., Courchamp F., Galil B., García-Berthou E., PASCAl M., PyŠEK P., Sousa R., TABACChi E., VilÀ M. (2013). Impacts of biological invasions: what's what and the way forward. Trends Ecol. Evol., 28: 58-66. doi: 10.1016/j.tree.2012.07.013

SPeAR D., FoxCROFT L.C., Bezuidenhout H., MCGEOCH M.A. (2013). Human population density explains alien species richness in protected areas. Biol. Conserv., 159: 137-147. doi: 10.1016/j.biocon.2012.11.022

STATSOFT INC., S. (2013). STATISTICA (data analysis software system), version 10. URL: http://www.statsoft.com [10/09/2018]

THEOHARIDES K.A., DUKES J.S. (2007). Plant invasion across space and time: factors affecting nonindigenous species success during four stages of invasion. New Phytol., 176: 256-273. doi: 10.1111/j.14698137.2007.02207.x

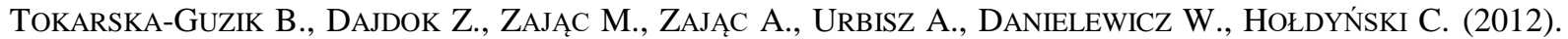
Rośliny obcego pochodzenia w Polsce ze szczególnym uwzględnieniem gatunków inwazyjnych. Warszawa: Generalna Dyrekcja Ochrony Środowiska, 197 p. (in Polish)

VAN EMDEN H. (2008). Statistics for terrified biologists. USA, UK, Australia: Blackwell Publishing, 343 p.

Vilà M., Basnou C., Pyšek P., Josefsson M., Genovesi P., Gollasch S., Nentwig W., Olenin S., Roques A., RoY D., Hulme P.E. AND DAISIE PARTNERS. (2009). How well do we understand the impacts of alien species on ecosystem services? A pan-European, cross-taxa assessment. Front. Ecol. Environ., 8(3): 135-144, doi:10.1890/080083

Рекомендує до друку

Отримано 24.01.2019

Мойсієнко I.I.

Aдреси авторів:

А. Бомановска

Кафедра геоботаніки та Екології рослин

Факультет біологї та захисту довкілля

Університет Лоди

Банача 12/16, 90-237, Лоди

Польща

e-mail: anna.bomanowska@biol.uni.lodz.pl

\section{I. Кирплюк}

Вапшавський університет, Факультет біології, Ботанічний сад

вул. Уяздовськи 4, 00-478 Варшава

Польщза

e-mail: ikirpluk@biol.uw.edu.pl

\section{А. Отреба}

Начіональний природний парк Кампінос

Тетмаєра 38, 05-080 Ізабелін

Польщча

e-mail:aotreba@kampinoski-pn.gov.pl

\author{
Authors' addresses: \\ A. Bomanowska \\ Department of Geobotany and Plant Ecology, Faculty \\ of Biology and Environmental Protection, University \\ of Łódź \\ Banacha 12/16, 90-237 Łódź \\ Poland \\ e-mail: anna.bomanowska@biol.uni.lodz.pl \\ I. Kirpluk \\ Botanic Garden, Faculty of Biology, University of \\ Warsaw \\ Al. Ujazdowskie 4, 00-478 Warsaw \\ Poland \\ e-mail:ikirpluk@biol.uw.edu.pl \\ A.Otręba \\ Kampinoski National Park \\ Tetmajera 38, 05-080 Izabelin \\ Poland \\ e-mail:aotreba@kampinoski-pn.gov.pl
}

